Article

\title{
Effect of Temperature and Mineral Matter on the Formation of NOx Precursors during Fast Pyrolysis of 2,5-Diketopiperazine
}

\author{
Jianqiang Zhou, Pan Gao ${ }^{\circledR}$, Changqing Dong * and Yongping Yang \\ National Engineering Laboratory for Biomass Power Generation Equipment, \\ North China Electric Power University, Beijing 102206, China; jianqiangzhou@126.com (J.Z.); \\ gaopan@ncepu.edu.cn (P.G.); yyp@ncepu.edu.cn (Y.Y.) \\ * Correspondence: dongcq@ncepu.edu.cn; Tel.: +86-10-6177-2030
}

Received: 11 February 2018; Accepted: 8 March 2018; Published: 12 March 2018

\begin{abstract}
DKP) was used as a N-containing model compound to investigate the formation pathway of $\mathrm{NOx}$ precursors $\left(\mathrm{HCN}, \mathrm{NH}_{3}\right.$, and $\left.\mathrm{HNCO}\right)$ during biomass pyrolysis. The experiment was carried out using a tube furnace coupled with a Fourier Transform Infrared Spectrometer in an argon atmosphere. The results showed that $\mathrm{NH}_{3}, \mathrm{HCN}$, and $\mathrm{HNCO}$ were the major N-containing species formed during DKP fast pyrolysis. The largest yield was $\mathrm{HCN}$, followed by $\mathrm{NH}_{3}$ and lastly $\mathrm{HNCO}$. When the pyrolysis temperature was increased, the yield of $\mathrm{NH}_{3}$ increased slowly, but the yield of $\mathrm{HCN}$ decreased slightly at $800 \sim 950^{\circ} \mathrm{C}$ and the change accelerate rapidly above $950{ }^{\circ} \mathrm{C}$. Then $\mathrm{NH}_{3}$ became the main product above $1020^{\circ} \mathrm{C}$. The temperature influence was negligible on the selectivity between $\mathrm{HCN}$ and $\mathrm{NH}_{3}$ from pyrolysis of DKP. H radicals played an important role in competitive reactions. It was also noted that the presence of $\mathrm{Na}^{+}, \mathrm{K}^{+}, \mathrm{Ca}^{2+}$, and $\mathrm{Mg}^{2+}$ exhibited a catalytic effect on nitrogen conversion during the DKP fast pyrolysis process. $\mathrm{K}^{+}$and $\mathrm{Na}^{+}$were beneficial to the yield of $\mathrm{NH}_{3}$, but not to the yield of $\mathrm{HCN}$. $\mathrm{Ca}^{2+}$ and $\mathrm{Mg}^{2+}$ could promote the formation of $\mathrm{HCN}$, but prevent the formation of $\mathrm{NH}_{3}$.
\end{abstract}

Keywords: biomass; nitrogen-containing model compounds; fast pyrolysis; 2,5-diketopiperazine; nitrogen conversion

\section{Introduction}

The combustion of biomass usually produces harmful nitrogen oxides due to the high nitrogen content of the biomass, which threatens the environment. Therefore, the study of the conversion of fuel nitrogen in the process of biomass combustion utilization has attracted wide public interest [1-5]. Due to the complex composition and diverse form of the molecules containing nitrogen in biomass, it is difficult to confirm migration mechanisms of the fuel nitrogen by direct pyrolysis of the biomass [6]. In an alternative approach, many researchers have used model compounds with defined molecular structures to study the transformation mechanism of fuel nitrogen in biomass [2,3,7,8]. Many amino acids have been selected as model compounds, since protein is one of the major nitrogen-containing materials in biomass, and a large group of organic molecules is formed by amino acid condensation water reaction. Pyrolysis of the protein generates 3-R,6-R'-2,5-Diketopiperazine (DKPs) [9-13] via peptide bond cleavage. Although the primary reaction of amino acid pyrolysis is formation of DKPs, there are also other reaction pathways, including deamination, dehydration, and decarboxylase [14-17] during pyrolysis. Therefore, the pyrolysis reactions of amino acids may be inconsistent with those of proteins in biomass. Therefore, recently, 2,5-diketopiperazine (DKP), the simplest DKP, has often been used as a model compound for the study of biomass pyrolysis $[3,9]$. 
Hansson et al. [9] investigated the gas release from a fast pyrolysis of the DKP in fluidized bed reactor and demonstrated that the primary pyrolysis gases containing nitrogen were $\mathrm{HCN}, \mathrm{NH}_{3}$, and $\mathrm{HNCO}$. The yield of $\mathrm{HCN}$ was larger than that of $\mathrm{NH}_{3}$, and the yield of $\mathrm{HNCO}$ was the least. In our previous work [3], a TG-FTIR test system was used to study slow heating pyrolysis of DKP. Our results showed that although the $\mathrm{NH}_{3}, \mathrm{HCN}$ and $\mathrm{HNCO}$ were the primary nitrogenous gases released during DKP pyrolysis, the yield of $\mathrm{NH}_{3}$ was the largest, followed by those of $\mathrm{HCN}$ and HNCO. The distribution of nitrogen-containing gases released from DKP pyrolysis was almost the opposite under the two different experiment conditions. The release of tar was dependent on the particle diameter of DKP and the heating rate of the fuel, which further influenced the distribution of fuel nitrogen in gaseous products [4,18-21]. In addition, DKP was put into the reactor in different ways in Hansson's [9] and our experiments [3]. It is difficult to confirm the mechanism of DKP pyrolysis, because temperature field difference in the DKP particles results in pyrolysis products that influence each other. $\mathrm{NH}_{3}$ is the main product of amino acid and DKP pyrolysis $[3,9,22,23]$. Amino acids mainly generate $\mathrm{NH}_{3}$ by deamination or amine hydrogenation $[17,24]$, but studies on rapid DKP pyrolysis have not provided the generation pathways of $\mathrm{NH}_{3}[7,9,25]$. In slow pyrolysis, some scholars $[3,26]$ believe that under the catalytic action of char, $\mathrm{H}$ radicals react with char nitrogen to generate $\mathrm{NH}_{3}$. However, in rapid pyrolysis, there is little char formation, so it is necessary to study the generation pathways of $\mathrm{NH}_{3}$ in the rapid pyrolysis of DKP.

This study intends to confirm the migration mechanism of the formation of NOx precursors during rapid pyrolysis of DKP. In order to reduce the influence of the DKP particle diameter, a DKP solution spray reactor was used, since the moisture content of biomass is of a higher level [27], and $\mathrm{H}_{2} \mathrm{O}$ is stable below $2500 \mathrm{~K}$ [28]. The distribution of NOx precursors in the product was investigated during rapid pyrolysis of the DKP.

There are some mineral elements in biomass that have certain catalytic effects on the pyrolysis of biomass nitrogen. Reports on the rapid pyrolysis of a mix of DKP and mineral elements have not been found to date. For information about the mechanism of protein pyrolysis, the effects of the presence of $\mathrm{K}^{+}, \mathrm{Na}^{+}, \mathrm{Ca}^{2+}$, and $\mathrm{Mg}^{2+}$ on the gas-N release of DKP were examined. The results suggested that the temperature influence was negligible, while $\mathrm{H}$ radicals might play an important role in the selectivity of $\mathrm{HCN}$ and $\mathrm{NH}_{3} \cdot \mathrm{K}^{+}, \mathrm{Na}^{+}, \mathrm{Ca}^{2+}$, and $\mathrm{Mg}^{2+}$ effected the NOx precursors release during DKP pyrolysis.

\section{Experimental}

\subsection{Apparatus}

Pyrolysis experiments were carried out using a tube furnace reactor coupled with a Fourier Transform Infrared (FTIR) spectrometer. Figure 1 shows a schematic diagram of the fast pyrolysis system. The reactor was made of a cylindrical quartz tube with an inner diameter of $25 \mathrm{~mm}$ and a length of $800 \mathrm{~mm}$. The reactor tube was placed in a vertical tube furnace, the temperature of which was determined by a heating power controller. To ensure that the sample could be sent evenly into the pyrolysis zone, a quartz glass spray nozzle was selected as an entrance of carrier gas and sample solution. The sample solution was sent into the spray nozzle by a piston metering pump, and the solution was sprayed into the reactor under the drive of carrier gas. The experiment was performed in argon, which was used as a carrier gas, as well as the background atmosphere of the pyrolysis. The flow rate of the argon was controlled by the mass flow controller (MFC). Reaction gases were withdrawn from the bottom of the reactor, and then transported into the FTIR system by a heated transfer pipe at $180^{\circ} \mathrm{C}$. A high-performance FTIR (ABB, MB3000) was used for gas analyses. The FTIR spectra were obtained at wavelengths between 450 and $4000 \mathrm{~cm}^{-1}$ and a resolution of $8 \mathrm{~cm}^{-1}$. The FTIR was calibrated before the experiment and simultaneously detects $\mathrm{C}_{2} \mathrm{H}_{4}, \mathrm{CH}_{4}, \mathrm{CO}, \mathrm{CO}_{2}, \mathrm{HCN}, \mathrm{HNCO}$, $\mathrm{NH}_{3}, \mathrm{NO}, \mathrm{NO}_{2}$, and other gases. A linear relation between a given wave number absorbance (A) and concentration (c) of gas compounds is expected in an ideal case. Gas specific absorptivity (a) is a function of the wavenumber and can be calculated in a standard sample test. The concentration of 
the test gas is determined according to the Beer-Lambert Law $(A=a b c)[10,29]$, where $b$ is the optical path length $(\mathrm{cm})$. The FTIR data are recorded and transformed into the volume concentration of the gas by analyzing the software automatically.

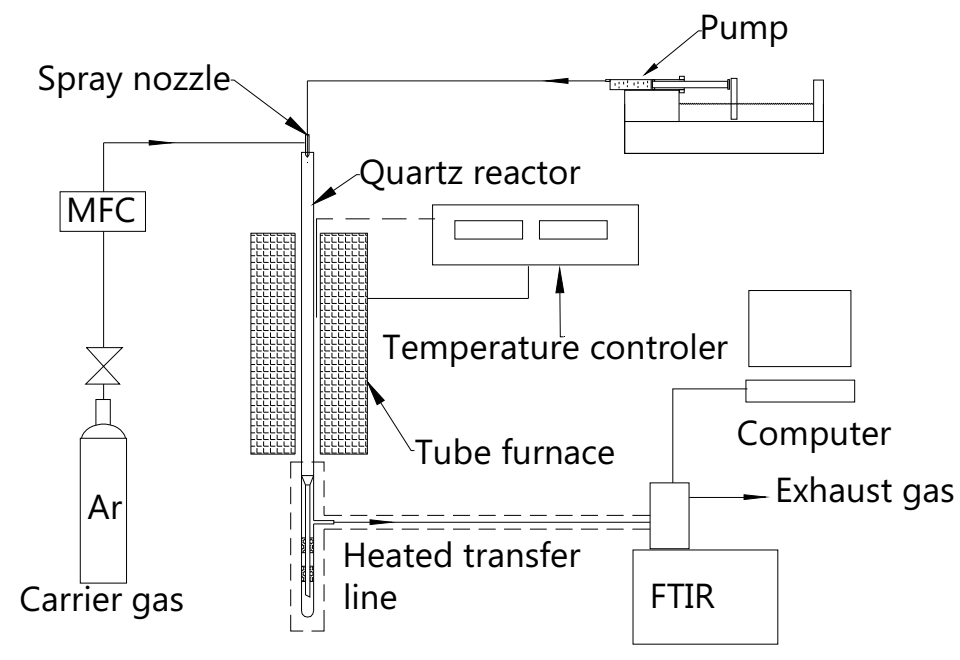

Figure 1. The schematic diagram of the fast pyrolysis system.

\subsection{Materials}

DKP (purity > 99\%), $\mathrm{NaCl}, \mathrm{KCl}, \mathrm{MgCl}_{2}$, and $\mathrm{CaCl}_{2} \cdot 2 \mathrm{H}_{2} \mathrm{O}$ (purity $>98 \%$ ) were purchased from Alfa Aesar (China) Chemical Co., Ltd. (Shanghai, China). Three groups of DKP solutions were needed in this study. The first was a pure DKP solution at a concentration of $5 \mathrm{mg} / \mathrm{L}$ by dissolving DKP in deionized water. The second group included four DKP solutions. In solution $\mathrm{A}, \mathrm{NaCl}$ content of $4 \mathrm{wt} \%$ of DKP was added to the original DKP solutions $(5 \mathrm{mg} / \mathrm{L})$. In solution $\mathrm{B}$, solution $\mathrm{C}$, and solution $\mathrm{D}, \mathrm{KCl}, \mathrm{MgCl}_{2}$, and $\mathrm{CaCl}_{2} \cdot 2 \mathrm{H}_{2} \mathrm{O}$ were added, respectively, to the original DKP solutions in the same amount as solution $\mathrm{A}$. The last solution contained the four minerals in the original DKP solution (5 mg/L) prepared with element contents of $\mathrm{K} 3.88 \mathrm{wt} \%$, Na $0.34 \mathrm{wt} \%$, Ca $1.05 \mathrm{wt} \%$, and $\mathrm{Mg}$ $0.77 \mathrm{wt} \%$, in accordance with the content of the elements in rice straw in China as a model biomass system [30].

\subsection{Pyrolysis Experiments}

The carrier gas in the experiment was high-purity argon (>99.999\%). The argon flow rate was $1 \mathrm{~L} / \mathrm{min}$. The flow rate of the piston metering pump was $1 \mathrm{~mL} / \mathrm{min}$. The total concentration of gas-phase nitrogen (Gas-N) is theoretically 196 ppm if DKP is completely converted into NOx. Content of $\mathrm{H}_{2} \mathrm{O}$ is $12.4 \%(v / v)$, which is similar, on an average, to the exhaust gas from a biomass combustion boiler.

Combustion temperature in a biomass boiler is usually no more than $1000{ }^{\circ} \mathrm{C}$. Therefore, the pyrolysis experiments were performed at eight temperatures $\left(700{ }^{\circ} \mathrm{C}, 750{ }^{\circ} \mathrm{C}, 800{ }^{\circ} \mathrm{C}, 850{ }^{\circ} \mathrm{C}\right.$, $900{ }^{\circ} \mathrm{C}, 950{ }^{\circ} \mathrm{C}, 1000^{\circ} \mathrm{C}$, and $1050^{\circ} \mathrm{C}$ ). The tube furnace was heated to the set point. The FTIR was powered on at the gas cell temperature of $250{ }^{\circ} \mathrm{C}$ and $980 \mathrm{mbar}$. Then, the metering pump was turned on to spray the DKP solution into the reactor. The data measured by the FTIR should be held steady for at least last $15 \mathrm{~min}$. The arithmetic mean of the 5 data in stable condition was determined as the final experimental data. All experiments were conducted in two runs, and the error was within 5\%. 


\section{Results and Discussion}

\subsection{Distribution of Gas-N Products for Fast DKP Pyrolysis under Stable Temperature}

The FTIR spectrum of the small molecular gaseous species of DKP pyrolysis is shown in Figure 2. The primary gaseous products, including $\mathrm{HCN}, \mathrm{NH}_{3}, \mathrm{H}_{2} \mathrm{O}, \mathrm{HNCO}$, and $\mathrm{CO}_{2}$, are easily identified by their characteristic absorbance: $\mathrm{HCN}$ at $714 \mathrm{~cm}^{-1} ; \mathrm{NH}_{3}$ at $966 \mathrm{~cm}^{-1} ; \mathrm{H}_{2} \mathrm{O}$ at $1500 \sim 1600 \mathrm{~cm}^{-1}$; $\mathrm{HNCO}$ at $2250 \mathrm{~cm}^{-1}$, and $\mathrm{CO}_{2}$ at $2358 \mathrm{~cm}^{-1}$.

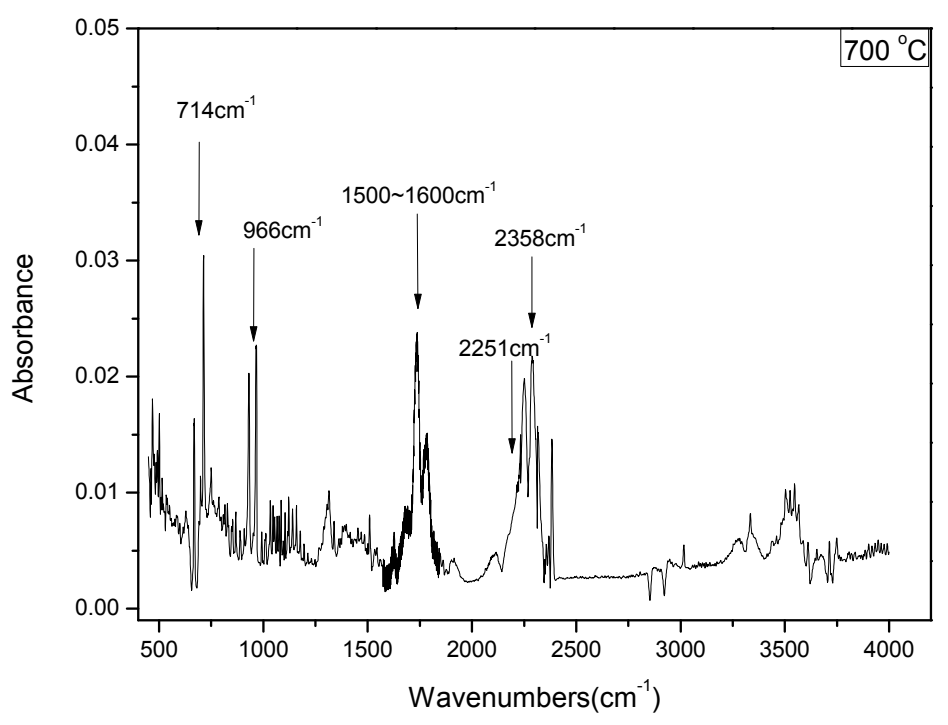

Figure 2. The FTIR spectra of the evolved gas from pyrolysis of DKP at $700{ }^{\circ} \mathrm{C}$.

The amounts of $\mathrm{C}_{2} \mathrm{H}_{4}, \mathrm{CO}$ and $\mathrm{CO}_{2}$ were nearly equal to each other. The content of $\mathrm{H}_{2} \mathrm{O}$ was the largest, at approximately $12.4 \%(v / v)$. Most of the water was introduced by the sample solution, and only very little was released from pyrolysis. $\mathrm{HCN}, \mathrm{HNCO}, \mathrm{NH}_{3}$ and $\mathrm{NO}$ were the main Gas-N species, which were the focus of this study.

Figure 3 indicates the yield of $\mathrm{HCN}, \mathrm{HNCO}, \mathrm{NH}_{3}$ and $\mathrm{NO}$ at different pyrolysis temperatures. It was found that $\mathrm{HCN}$ exhibited the largest yield, at above $110 \mathrm{ppm}$, as the main nitrogen product in all of the Gas-Ns at 700 900 ${ }^{\circ} \mathrm{C}$. The yield of HCN increased gradually with the increase of temperature. The output of $\mathrm{HCN}$ decreased slowly at $800 \sim 950{ }^{\circ} \mathrm{C}$ and then declined rapidly when the temperature was greater than $950^{\circ} \mathrm{C}$. The yield of $\mathrm{NH}_{3}$ was relatively less than $\mathrm{HCN}$, and decreased slightly with the increase of temperature $700 \sim 800{ }^{\circ} \mathrm{C}$. At $800{ }^{\circ} \mathrm{C}$, the yield of $\mathrm{NH}_{3}$ reached its lowest amount at $47.53 \mathrm{ppm}$ and then began to ascend slowly at $800 \sim 950{ }^{\circ} \mathrm{C}$, then suddenly and rapidly rising at $950{ }^{\circ} \mathrm{C}$. The yield of HNCO was relatively small, but HNCO demonstrated a different behavior when the temperature was changed. The yield of HNCO decreased slowly at 700 850 ${ }^{\circ} \mathrm{C}$ and reached a local minimum point of $7.50 \mathrm{ppm}$ at $850^{\circ} \mathrm{C}$. However, it began to rise again to its highest point, $14.79 \mathrm{ppm}$, at $1000{ }^{\circ} \mathrm{C}$ before decreasing again. The Gas-N release of DKP pyrolysis at $700 \sim 850{ }^{\circ} \mathrm{C}$ in this study was nearly the same as the results reported by Hansson et al. [9]. In their study, the yield of $\mathrm{NH}_{3}$ was always higher than that of $\mathrm{HNCO}$, but less than $\mathrm{HNCO}$ below $800{ }^{\circ} \mathrm{C}$. However, the two studies showed different results at $800 \sim 1050{ }^{\circ} \mathrm{C}$. In Hansson's study [9], the yield rose with the increase of the temperature. The change of the $\mathrm{HCN}$ yield was slow. The yield of $\mathrm{NH}_{3}$ rose slightly. On the other hand, our results showed that the yield of $\mathrm{HCN}$ began to decline slowly at $800{ }^{\circ} \mathrm{C}$. The yield of $\mathrm{NH}_{3}$ began to rise slowly at $800{ }^{\circ} \mathrm{C}$, but the increase suddenly began to speed up at $950{ }^{\circ} \mathrm{C}$. The total yield of nitrogenous compounds in Gas-N was 180 200 ppm at the pyrolysis temperature, which was equal to the nitrogen content of the DKP added into the rector. These results clearly demonstrated the competitive relationship between different reaction paths to $\mathrm{NH}_{3}$ or $\mathrm{HCN}$ during the pyrolysis of DKP. 
No similar phenomena were reported in Hansson [9] or other previous work [17,31]. These results illustrated the accuracy of the experimental method in our study.

The distribution of Gas-N products from the pyrolysis in this study was quite different from our previous study [3] of the pyrolysis of DKP using the TG-FTIR device, as well as from other [3,9,17,31] pyrolysis studies of DKP or Glycine. A summary of previous work is given in Table 1.

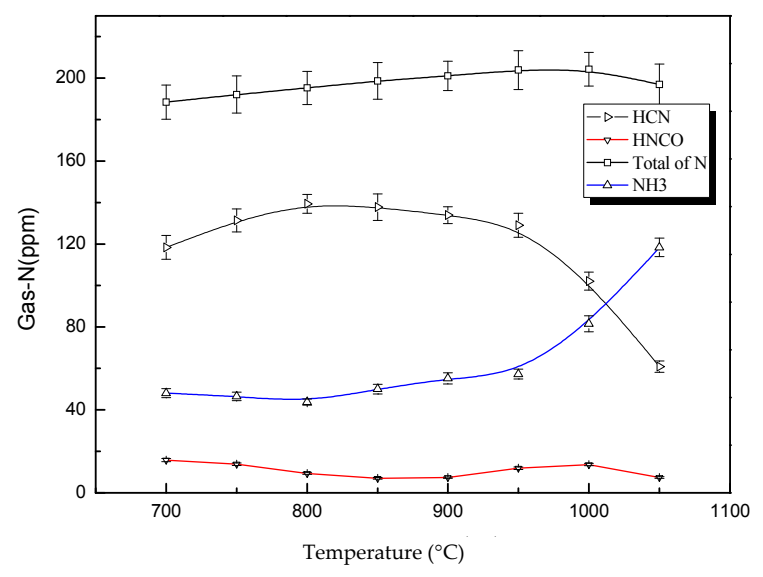

Figure 3. Effects of pyrolysis temperature on product yields.

Table 1. Yields of Gas-N from pyrolysis of the nitrogen-containing model.

\begin{tabular}{cccccccc}
\hline \multirow{2}{*}{ Sample } & \multirow{2}{*}{ Pyrolysis Device } & \multirow{2}{*}{ Heating Rate } & \multirow{2}{*}{ Temperature $/{ }^{\circ} \mathbf{C}$} & \multicolumn{4}{c}{ Gas-N/\% } \\
\cline { 5 - 6 } & & & & $\mathbf{H C N}$ & $\mathbf{N H}_{\mathbf{3}}$ & $\mathbf{H N C O}$ & Reference \\
\hline Glycine & Quartz tube & Fast & 800 & 43.7 & 46.4 & 9.9 & {$[31]$} \\
Glycine & GC-MS & Fast & 500 & 41.0 & 59.0 & n.a. & {$[17]$} \\
DKP & TG-FTIR & Slow & $20 \sim 800$ & 28.6 & 54.3 & 17.1 & {$[3]$} \\
DKP & Fluidized bed & Fast & 800 & 79 & 9 & 12 & {$[9]$} \\
DKP & Quartz tube & Fast & 800 & 69.2 & 25.1 & 5.7 & This study \\
\hline
\end{tabular}

DKP is a cyclo dipeptide compound formed by intermolecular dehydration between two glycines, and the main primary product of glycine pyrolysis [14-17] is DKP. Simmonds et al. [17] rapidly pyrolyzed model compounds of glycine. Although DKP is the primary pyrolysis product of glycine, other products were also formed through intramolecular dehydration, decarboxylation, and deamination reaction, so there were great differences between the yields of gas- $\mathrm{N}$ released from DKP pyrolysis in this study and from glycine pyrolysis in Simmonds et al. [17].

Zhou et al. [3] pyrolyzed DKP using a thermogravimetric analyzer (TGA). Because the samples were stacked in a crucible, the internal volatiles of the DKP particles encountered larger resistance during the escape process, and were polymerized into char [32]. The DKP char produced more $\mathrm{NH}_{3}$, so the yield of $\mathrm{NH}_{3}$ was higher than of $\mathrm{HCN}$ in the Zhou et al. [3] study.

Ren [31] investigated Gas-N release of glycine pyrolysis. Because the samples were stacked in a ceramic boat heated in the tube furnace, the thermal resistance of the samples was also higher. The experiment was closer to slow pyrolysis and resulted in the formation of more char nitrogen, from which it is easier to generate $\mathrm{NH}_{3}$ [33], as shown in Figure 4.

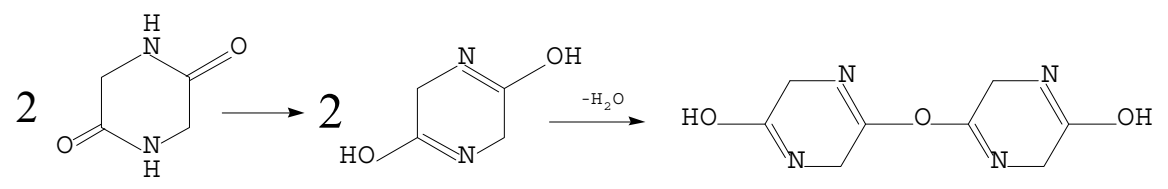

Figure 4. Dehydration reaction between two DKP molecules. 
The low-temperature tar of DKP pyrolysis may affect the Gas-N distribution. If tar cracking occurs quickly, pyrolysis of DKP will produce more $\mathrm{HCN}$, and if the tar was polymerized to produce char, the pyrolysis of DKP transformed mainly to $\mathrm{NH}_{3}$.

\subsection{Decomposition Path Analysis of Fast Pyrolysis DKP}

Our previous study [3] reported that DKP pyrolysis occurs in two stages. At the first stage, the majority of the DKP molecules are split into small molecules [25], and a small amount of DKP molecules is polymerized to produce char [31], as illustrated in Figure 4. At the second stage, the small molecules generate Gas-N, hydrocarbons, and carbon oxide compounds, as shown in Figure 5.

Figure 5 shows that due to the symmetry of the DKP molecule, the bond breaks from the first and third positions will generate the same product lactone. However, if there are many $\mathrm{H}$ radicals around the DKP molecules, DKP will generate 2-Aminoacetaldehyde by the first reaction pathway.

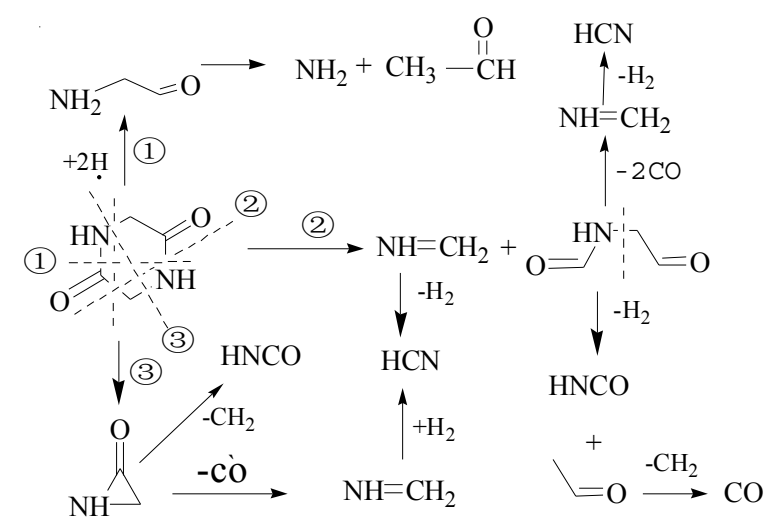

Figure 5. The potential pathway for pyrolysis of DKP.

When the DKP was rapidly pyrolyzed in this study, the main reaction pathway to form HCN fragments was the second path in Figure 5, and only a little $\mathrm{HCN}$ was produced from the third path in Figure 6. $\mathrm{HNCO}$ and $\mathrm{CH}_{2}$ radicals are produced through lactone. The reaction of $\mathrm{CH}_{2}$ radicals and $\mathrm{H}$ radicals may form $\mathrm{CH}_{4}$, and the yield of $\mathrm{CH}_{4}$ was about 10 20 ppm in our experiment. This suggested that some DKP had produced $\mathrm{HNCO}$ and $\mathrm{CH}_{2}$ via lactone. The main pathway for generating $\mathrm{NH}_{3}$ is the first pathway, but this requires $\mathrm{H}$ radicals to break the $\mathrm{C}-\mathrm{N}$ bonds. Therefore, the yield of $\mathrm{NH}_{3}$ is relatively small at the low-temperature stage because of the lack of $\mathrm{H}$ radicals in the reaction.

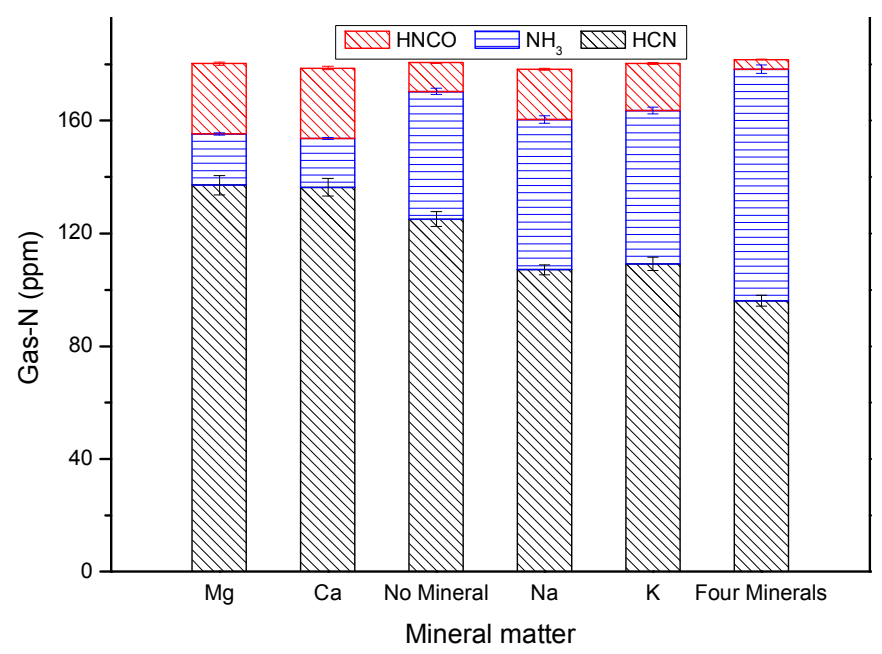

Figure 6. Effect of included mineral matter on NOx precursor release from DKP prolysis. 
However, a different behavior was exhibited at the high-temperature stage. $\mathrm{H}_{2} \mathrm{O}$ molecules might crack on the surface of the quartz reactor, producing a large number of $\mathrm{H}$ and $\mathrm{OH}$ radicals $[34,35]$. In the experiment, the yield of $\mathrm{HCN}$ began to decrease rapidly at $950{ }^{\circ} \mathrm{C}$, and that of $\mathrm{NH}_{3}$ increased sharply due to the mass production of $\mathrm{H}$ radicals by water. The pyrolysis pathway of DKP transfers from the second or third path to the first path in Figure 5.

It has previously been reported [26] that HCN can be combined with $\mathrm{H}$ free radicals to produce $\mathrm{NH}_{3}$ at high temperatures with a catalyst of char. However, a DKP solution was used in our experiment, and therefore, the DKPs almost completely transformed into gas without the formation of coke, according to nitrogen balance estimations. Therefore, it was almost impossible for $\mathrm{HCN}$ to produce $\mathrm{NH}_{3}$ directly.

\subsection{Analysis of the Catalytic Effect of Minerals on Rapid Pyrolysis of DKP}

Minerals are important components of biomass [36,37]. Minerals have an important influence on the distribution of nitrogen-containing compounds released from biomass pyrolysis [29,38-42]. Figure 6 shows that mineral matter has a significant effect on the formation of major Gas-N release from fast pyrolysis of DKP.

Figure 6 shows that the total amounts of the three nitrogen-containing gases- $\mathrm{HCN}, \mathrm{HNCO}$ and $\mathrm{NH}_{3}$ - exhibit little change after minerals were added into the DKP solution, which is in agreement with observations in the literature [29]. However, the yields of different gaseous products changed significantly. Magnesium and calcium promoted the formation of $\mathrm{HCN}$ and $\mathrm{HNCO}$ and inhibited that of $\mathrm{NH}_{3}$ [37].

The elements potassium and sodium promoted the formation of $\mathrm{NH}_{3}$ and inhibited HCN formation. Little effect was found on the formation of HNCO. It was also found that the promotion and inhabitation of Gas-N were significant at the pyrolysis of DKP that was added into the mixture of four minerals. The catalysis of the mixture was closer to the catalysis of the mineral potassium, which was the most mineral according to the proportion of mineral elements in the biomass, in which the proportion of potassium is largest, followed by calcium and sodium. The total amount of mineral elements was increased, and hence the promotion effect was enhanced [29].

Figure 7 shows the yield change of NOx precursors released from fast pyrolysis DKP blended with potassium at different temperatures. Symbols marked $\mathrm{K}$ stand for gas from pyrolysis of DKP mixed $\mathrm{KCl}$. After adding $\mathrm{KCl}$ to DKP, the yield trend of gas release from fast pyrolysis of DKP did not change. Potassium promotes $\mathrm{N}$-conversion to $\mathrm{NH}_{3}$ and decreases the formation of $\mathrm{HCN}$ at the temperature of $800 \sim 1000^{\circ} \mathrm{C}$, and catalysis to $\mathrm{HCN}$ reaches its maximum value at around of $900{ }^{\circ} \mathrm{C}$.

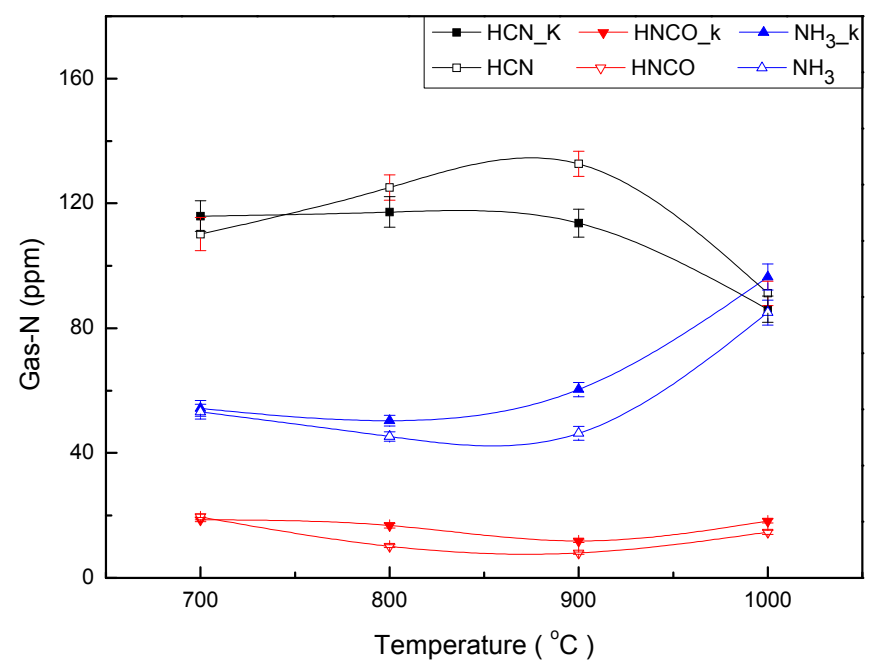

Figure 7. Yield of N-containing species from DKP pyrolysis, including $\mathrm{KCl}$. 
These observations suggest that $\mathrm{Ca}^{2+}$ and $\mathrm{Mg}^{2+}$ addition enhances $\mathrm{HCN}$ formation during pyrolysis of DKP by intermediates $\mathrm{Ca}(\mathrm{CN})_{2}$ and $\mathrm{Mg}(\mathrm{CN})_{2}$, which are stable chemical compounds [43]. $\mathrm{Cl}^{-}$from additions $\mathrm{CaCl}_{2}$ or $\mathrm{MgCl}_{2}$ in this study would promote $\mathrm{Ca}(\mathrm{CN})_{2}$ and $\mathrm{Mg}(\mathrm{CN})_{2}$ transformation into $\mathrm{HCN}$ at high temperature [42]. It is likely that $\mathrm{HCN}$ is formed through the following reaction:

$$
\mathrm{Ca}^{2+}+2 \mathrm{R}-\mathrm{C}-\mathrm{N} \stackrel{-2 \mathrm{R}^{+}}{\longrightarrow} \mathrm{Ca}(\mathrm{CN})_{2} \stackrel{+2 \mathrm{H}^{+}}{\longrightarrow} 2 \mathrm{HCN}+\mathrm{Ca}^{2+}
$$

$\mathrm{CaCl}_{2}$ or $\mathrm{MgCl}_{2}$ cannot catalyze $\mathrm{HCN}$ to form $\mathrm{NH}_{3}$, as that of $\mathrm{CaO}$ or $\mathrm{Ca}(\mathrm{OH})_{2}$ [41,42,44]. It suggests that $\mathrm{CaCl}_{2}$ or $\mathrm{MgCl}_{2}$ are able to enhance DKP pyrolysis reactions via the second and the third pathways in Figure 5.

The effects of the $\mathrm{K}^{+}$and $\mathrm{Na}^{+}$on DKP pyrolysis are different from that of $\mathrm{Ca}^{2+}$ and $\mathrm{Mg}^{2+}$. $\mathrm{KCN}$ and $\mathrm{NaCN}$ are unstable compounds at $800{ }^{\circ} \mathrm{C}$ and cannot generate $\mathrm{HCN}$ through $\mathrm{KCN}$ and $\mathrm{NaCN}$ intermediates [45]. However, at a lower temperature such as $700{ }^{\circ} \mathrm{C}$, some of the $\mathrm{HCN}$ may be evolved through the intermediates of $\mathrm{NaCN}$ and $\mathrm{KCN}$. As can be seen in Figure 7, the yield of $\mathrm{HCN}$ formation from DKP mixed $\mathrm{K}^{+}$exceeded that of $\mathrm{HCN}$ formation from DKP without any additives at $700{ }^{\circ} \mathrm{C}$. $\mathrm{Na}^{+}$or $\mathrm{K}^{+}$can also promote the decomposition of tar to produce $\mathrm{NH}_{3}[40,43]$. The $\mathrm{NH}_{3}$ increase resulting from the addition of $\mathrm{Na}^{+}$or $\mathrm{K}^{+}$originates mostly tar- $\mathrm{N}$ decomposition [45]. DKP is similar to the tar structure, which may be the reason why $\mathrm{Na}^{+}$and $\mathrm{K}^{+}$promote $\mathrm{NH}_{3}$ generation.

\section{Conclusions}

DKPs are ideal model compounds for studying the mechanism of NOx generation in biomass combustion. The main gaseous nitrogen-containing substances released from fast glycine-DKP pyrolysis are $\mathrm{HCN}, \mathrm{NH}_{3}$ and $\mathrm{HNCO}$. The yield of $\mathrm{HCN}$ is the highest, and that of $\mathrm{HNCO}$ is the lowest. The temperature influence is poor on the selectivity between $\mathrm{HCN}$ and $\mathrm{NH}_{3}$ produced from pyrolysis of DKP. H radicals might play an important role in promoting DKP to produce 2-Aminoacetaldehyde and further conversion to $\mathrm{NH}_{3}$.

$\mathrm{K}^{+}, \mathrm{Na}^{+}, \mathrm{Ca}^{2+}$, and $\mathrm{Mg}^{2+}$ play a catalytic role in the transformation of nitrogen from DKP fast pyrolysis. $\mathrm{K}^{+}$and $\mathrm{Na}^{+}$promote the formation of $\mathrm{NH}_{3}$, inhibit $\mathrm{HCN}$ and had little effect on $\mathrm{HNCO}$. $\mathrm{Ca}^{2+}$ and $\mathrm{Mg}^{2+}$ have a significant effect on the release of $\mathrm{HCN}$ and HNCO and have an inhibitory effect on $\mathrm{NH}_{3}$.

Acknowledgments: The project was supported by the National Basic Research Program of China (973 Program, 2015CB251501) and the Fundamental Research Funds for Central Universities (2018ZD08, 2018MS033).

Author Contributions: Jianqiang Zhou and Pan Gao conceived and designed the experiments; Jianqiang Zhou performed the experiments; Jianqiang Zhou and Pan Gao analyzed the data; Changqing Dong contributed reagents, materials, analysis tools; Jianqiang Zhou wrote the paper; Yongping Yang performed manuscript review. All authors have read and approved the content of the manuscript.

Conflicts of Interest: The authors declare no conflict of interest.

\section{References}

1. Jones, J.M.; Lea-Langton, A.R.; Ma, L.; Pourkashanian, M.; Williams, A. Pollutants Generated by the Combustion of Solid Biomass Fuels; Springer: London, UK, 2014.

2. Chen, H.; Si, Y.; Chen, Y.; Yang, H.; Chen, D.; Chen, W. NO $\mathrm{N}_{x}$ precursors from biomass pyrolysis: Distribution of amino acids in biomass and Tar-N during devolatilization using model compounds. Fuel 2017, 187, 367-375. [CrossRef]

3. Zhou, J.-Q.; Gao, P.; Dong, C.-Q.; Yang, Y.-P. TG-FTIR analysis of nitrogen conversion during straw pyrolysis: A model compound study. J. Fuel Chem. Technol. 2015, 43, 1427-1432. [CrossRef]

4. Yang, J.; Chen, H.; Zhao, W.; Zhou, J. TG-FTIR-MS study of pyrolysis products evolving from peat. J. Anal. Appl. Pyrolysis 2016, 117, 296-309. [CrossRef] 
5. Ghouma, I.; Jeguirim, M.; Sager, U.; Limousy, L.; Bennici, S.; Däuber, E.; Asbach, C.; Ligotski, R.; Schmidt, F.; Ouederni, A. The potential of activated carbon made of agro-industrial residues in nox immissions abatement. Energies 2017, 10, 1508. [CrossRef]

6. Sánchez, E.; Rivero, R.M.; Ruiz, J.M.; Romero, L. Changes in biomass, enzymatic activity and protein concentration in roots and leaves of green bean plants (Phaseolus vulgaris L. Cv. Strike) under high $\mathrm{NH}_{4} \mathrm{NO}_{3}$ application rates. Sci. Hortic. 2004, 99, 237-248. [CrossRef]

7. Li, J.; Wang, Z.; Yang, X.; Hu, L.; Liu, Y.; Wang, C. Evaluate the pyrolysis pathway of glycine and glycylglycine by TG-FTIR. J. Anal. Appl. Pyrolysis 2007, 80, 247-253. [CrossRef]

8. Jie, L.; Yuwen, L.; Jingyan, S.; Zhiyong, W.; Ling, H.; Xi, Y.; Cunxin, W. The investigation of thermal decomposition pathways of phenylalanine and tyrosine by TG-FTIR. Thermochim. Acta 2008, 467, 20-29. [CrossRef]

9. Hansson, K.-M.; Samuelsson, J.; Åmand, L.-E.; Tullin, C. The temperature's influence on the selectivity between HNCO and HCN from pyrolysis of 2,5-diketopiperazine and 2-pyridone. Fuel 2003, 82, $2163-2172$. [CrossRef]

10. Hansson, K.-M.; Samuelsson, J.; Tullin, C.; Åmand, L.-E. Formation of HNCO, HCN, and $\mathrm{NH}_{3}$ from the pyrolysis of bark and nitrogen-containing model compounds. Combust. Flame 2004, 137, 265-277. [CrossRef]

11. Voorhees, K.J.; Zhang, W.; Hendricker, A.D.; Murugaverl, B. An investigation of the pyrolysis of oligopeptides by curie-point pyrolysis-tandem mass spectrometry. J. Anal. Appl. Pyrolysis 1994, 30, 1-16. [CrossRef]

12. Langhammer, M.; Lüderwald, I.; Simons, A. Analytical pyrolysis of proteins. Fresenius J. Anal. Chem. 1986, 324, 5-8. [CrossRef]

13. Wang, X.; Sheng, L.; Yang, X. Pyrolysis characteristics and pathways of protein, lipid and carbohydrate isolated from microalgae Nannochloropsis sp. Bioresour. Technol. 2017, 229, 119-125. [CrossRef] [PubMed]

14. Chiavari, G.; Galletti, G.C. Pyrolysis-Gas chromatography/mass spectrometry of amino acids. J. Anal. Appl. Pyrolysis 1992, 24, 123-137. [CrossRef]

15. Rodante, F.; Marrosu, G.; Catalani, G. Thermal analysis of some $\alpha$-amino acids with similar structures. Thermochim. Acta 1992, 194, 197-213. [CrossRef]

16. Tsuge, S.; Matsubara, H. High-resolution pyrolysis-gas chromatography of proteins and related materials. J. Anal. Appl. Pyrolysis 1985, 8, 49-64. [CrossRef]

17. Simmonds, P.G.; Medley, E.E.; Ratcliff, M.A.; Shulman, G.P. Thermal decomposition of aliphatic monoaminomonocarboxylic acids. Anal. Chem. 1972, 44, 2060-2066. [CrossRef]

18. Cao, J.-P.; Li, L.-Y.; Morishita, K.; Xiao, X.-B.; Zhao, X.-Y.; Wei, X.-Y.; Takarada, T. Nitrogen transformations during fast pyrolysis of sewage sludge. Fuel 2013, 104, 1-6. [CrossRef]

19. Chen, H.; Namioka, T.; Yoshikawa, K. Characteristics of tar, $\mathrm{NO}_{\mathbf{x}}$ precursors and their absorption performance with different scrubbing solvents during the pyrolysis of sewage sludge. Appl. Energy 2011, 88, 5032-5041. [CrossRef]

20. Neves, D.; Thunman, H.; Matos, A.; Tarelho, L.; Gómez-Barea, A. Characterization and prediction of biomass pyrolysis products. Prog. Energy Combust. Sci. 2011, 37, 611-630. [CrossRef]

21. Chen, H.; Wang, Y.; Xu, G.; Yoshikawa, K. Fuel-n evolution during the pyrolysis of industrial biomass wastes with high nitrogen content. Energies 2012, 5, 5418-5438. [CrossRef]

22. Sharma, R.K.; Chan, W.G.; Hajaligol, M.R. Product compositions from pyrolysis of some aliphatic $\alpha$-amino acids. J. Anal. Appl. Pyrolysis 2006, 75, 69-81. [CrossRef]

23. Hao, J.; Guo, J.; Ding, L.; Xie, F.; Xia, Q.; Xie, J. TG-FTIR, Py-two-dimensional GC-MS with heart-cutting and LC-MS/MS to reveal hydrocyanic acid formation mechanisms during glycine pyrolysis. J. Therm. Anal. Calorim. 2014, 115, 667-673. [CrossRef]

24. Ratcliff, M., Jr.; Medley, E.; Simmonds, P. Pyrolysis of amino acids. Mechanistic considerations. J. Organ. Chem. 1974, 39, 1481-1490. [CrossRef]

25. Becidan, M. Experimental Studies on Municipal Solid Waste and Biomass Pyrolysis. Ph.D. Thesis, Norwegian University of Science and Technology, Trondheim, Norway, 2007.

26. Bassilakis, R.; Zhao, Y.; Solomon, P.; Serio, M. Sulfur and nitrogen evolution in the Argonne coals. Experiment and modeling. Energy Fuels 1993, 7, 710-720. [CrossRef]

27. Zvicevičius, E.; Raila, A.; Čiplienè, A.; Černiauskienè, Ž.; Kadžiulienè, Ž.; Tilvikienè, V. Effects of moisture and pressure on densification process of raw material from Artemisia dubia wall. Renew. Energy 2018, 119, 185-192. [CrossRef] 
28. Kogan, A. Direct solar thermal splitting of water and on site separation of the products I. Theoretical evaluation of hydrogen yield. Int. J. Hydrogen Energy 1997, 22, 481-486. [CrossRef]

29. Ren, Q.; Zhao, C.; Wu, X.; Liang, C.; Chen, X.; Shen, J.; Tang, G.; Wang, Z. Effect of mineral matter on the formation of $\mathrm{NO}_{x}$ precursors during biomass pyrolysis. J. Anal. Appl. Pyrolysis 2009, 85, 447-453. [CrossRef]

30. Qin, J.; Yu, C.; Li, S.; Ma, X.; Wang, Q.; Fang, M.; Luo, Z. The transportation and transformation of alkali metals in Straw-Fired CFB boilers. Acta Energiae Sol. Sin. 2009, 5, 667-673. [CrossRef]

31. Ren, Q.; Zhao, C.; Chen, X.; Duan, L.; Li, Y.; Ma, C. $\mathrm{NO}_{\mathrm{x}}$ and $\mathrm{N}_{2} \mathrm{O}$ precursors $\left(\mathrm{NH}_{3}\right.$ and $\left.\mathrm{HCN}\right)$ from biomass pyrolysis: Co-pyrolysis of amino acids and cellulose, hemicellulose and lignin. Proc. Combust. Inst. 2011, 33, 1715-1722. [CrossRef]

32. Chiavari, G.; Fabbri, D.; Prati, S. Gas chromatographic-mass spectrometric analysis of products arising from pyrolysis of amino acids in the presence of hexamethyldisilazane. J. Chromatogr. A 2001, 922, 235-241. [CrossRef]

33. Tian, F.-J.; Yu, J.-L.; McKenzie, L.J.; Hayashi, J.-I.; Li, C.-Z. Conversion of Fuel-N into HCN and $\mathrm{NH}_{3}$ during the pyrolysis and gasification in steam: A comparative study of coal and biomass. Energy Fuels 2007, 21, 517-521. [CrossRef]

34. Gokon, N.; Takahashi, S.; Yamamoto, H.; Kodama, T. Thermochemical two-step water-splitting reactor with internally circulating fluidized bed for thermal reduction of ferrite particles. Int. J. Hydrogen Energy 2008, 33, 2189-2199. [CrossRef]

35. Kita, I.; Matsuo, S.; Wakita, $\mathrm{H} . \mathrm{H}_{2}$ generation by reaction between $\mathrm{H}_{2} \mathrm{O}$ and crushed rock: An experimental study on $\mathrm{H}_{2}$ degassing from the active fault zone. J. Geophys. Res. Solid Earth 1982, 87, 10789-10795. [CrossRef]

36. Hindiyarti, L. Gas Phase Sulfur, Chlorine and Potassium Chemistry in Biomass Combustion. Ph.D. Thesis, CHEC Research Centre, Department Chemical Engineering, Technical University of Denmark, Kgs. Lyngby, Denmark, 2007.

37. Gao, P.; Xue, L.; Lu, Q.; Dong, C. Effects of alkali and alkaline earth metals on N-containing species release during rice straw pyrolysis. Energies 2015, 8, 13021-13032. [CrossRef]

38. Liu, Z.; Balasubramanian, R. A comparative study of nitrogen conversion during pyrolysis of coconut fiber, its corresponding biochar and their blends with lignite. Bioresour. Technol. 2014, 151, 85-90. [CrossRef] [PubMed]

39. Jones, J.; Darvell, L.; Bridgeman, T.; Pourkashanian, M.; Williams, A. An investigation of the thermal and catalytic behaviour of potassium in biomass combustion. Proc. Combust. Inst. 2007, 31, 1955-1963. [CrossRef]

40. Ren, Q.; Zhao, C. NOx and $\mathrm{N}_{2} \mathrm{O}$ precursors $\left(\mathrm{NH}_{3}\right.$ and $\left.\mathrm{HCN}\right)$ from biomass pyrolysis: Interaction between amino acid and mineral matter. Appl. Energy 2013, 112, 170-174. [CrossRef]

41. Yi, L.L.; Liu, H.; Lu, G.; Zhang, Q.; Wang, J.X.; Hu, H.Y.; Yao, H. Effect of mixed Fe/Ca additives on nitrogen transformation during protein and amino acid pyrolysis. Energy Fuels 2017, 31, 9484-9490. [CrossRef]

42. Liu, H.; Zhang, Q.; Hu, H.Y.; Liu, P.; Hu, X.W.; Li, A.J.; Yao, H. Catalytic role of conditioner Cao in nitrogen transformation during sewage sludge pyrolysis. Proc. Combust. Inst. 2015, 35, 2759-2766. [CrossRef]

43. Zhao, Z.; Li, W.; Qiu, J.; Wang, X.; Li, B. Influence of $\mathrm{Na}$ and $\mathrm{Ca}$ on the emission of $\mathrm{NO}_{\mathrm{x}}$ during coal combustion. Fuel 2006, 85, 601-606. [CrossRef]

44. Tsubouchi, N.; Ohshima, Y.; Xu, C.; Ohtsuka, Y. Enhancement of $\mathrm{N}_{2}$ formation from the nitrogen in carbon and coal by calcium. Energy Fuels 2001, 15, 158-162. [CrossRef]

45. Ohtsuka, Y.; Zhiheng, W.; Furimsky, E. Effect of alkali and alkaline earth metals on nitrogen release during temperature programmed pyrolysis of coal. Fuel 1997, 76, 1361-1367. [CrossRef]

(C) 2018 by the authors. Licensee MDPI, Basel, Switzerland. This article is an open access article distributed under the terms and conditions of the Creative Commons Attribution (CC BY) license (http://creativecommons.org/licenses/by/4.0/). 